\title{
The Determinants of Relative Wage Change in Australia*
}

\author{
Elizabeth Webster and Yi-Ping Tseng \\ Melbourne Institute of Applied Economic and Social Research \\ The University of Melbourne
}

Melbourne Institute Working Paper No. 23/00

ISSN 1328-4991

ISBN 0734015038

December 2000

* This paper was funded by an ARC grant. Thanks are due to Joe Isaac, Mark Wooden, Jacqui Dwyer, Bruce Chapman, Don Harding and Jeff Borland. Views expressed represent those of the authors and all errors remain their responsibility.

Melbourne Institute of Applied Economic and Social Research

The University of Melbourne

Victoria 3010 Australia

Telephone (03) 83445330

Fax (03) 83445630

Email melb.inst@iaesr.unimelb.edu.au

WWW Address http://www.melbourneinstitute.com 


\begin{abstract}
This paper uses micro data from over 4000 Australian individuals to investigate which factors have had a significant influence on microeconomic wage growth over the past 3 years. The relative importance of four type of factors: outside incomes, demand for labour, workers' relative bargaining strength and category of wage contract are compared. Basic individual demographic characteristics (partial substitute variables for outside incomes), and some indicators of workers' bargaining power provided most of the explanation for wage changes. Proxy variables for labour demand, while significant and correctly signed, were small in magnitude. Information on workplace characteristics and the individual's work history were not available.
\end{abstract}




\section{Introduction}

Relative and nominal wages changes occupy an essential position within most economic theories. They are foremost in the theories of income distribution and the causes of poverty within nations. As part of the 'invisible hand' they are often ascribed the role of allocating labour between competing occupations and industries and among intertemporal education and training choices. Furthermore, wages, both relative and in aggregate, fulfil central macroeconomic functions. They form both the major cost of production as well as underpinning the major part of demand for consumption goods. In addition, changes to aggregate nominal wages may be an exogenous source of national inflationary pressure. Indeed, a review of the relevant literature suggests that collectively economists expect relative and absolute wages to perform many duties and that a determinant system of wages to cater for all purposes is not possible. ${ }^{1}$

Nevertheless, knowing the causes of relative wage changes still retains potential value to most economists. Quantifying the possible determinants of relative and nominal wages allows the numerous influences of secondary or hypothetical importance to be eliminated from analysis and policy discussions. Knowing important influences allows the analysis to focus more precisely on stronger systematic forces. This paper uses micro data from over 4000 Australian individuals to investigate which factors have had a significant influence on microeconomic wage change over the past 3 years. Specifically, the relative importance of three type of factors: individual characteristics, relative bargaining power (including market forces) and institutional factors are compared.

\footnotetext{
${ }^{1}$ That is, the system is over-determined.
} 
Only a limited number of disaggregated Australian studies of wage determination have been undertaken. ${ }^{2}$ Pooled cross sectional times series studies by Webster and Summers (2000), Withers et al. (1986) and Keating (1983) found that while industry had a consistent effect on wage levels, the coefficient for market forces was smaller and generally correctly signed but not always significant. Unit record data studies have analysed the determinants of comparative wage levels (hourly rates) but not their changes (Miller and Mulvey 1996, Borland and Suen 1990). While neither of these papers was able to test for the effects of market forces (as transmitted through labour market pressures) or worker bargaining power, the most important remaining variables include basic demographic variables (age, sex, educational qualification) and again industry. ${ }^{3}$ Unlike previous studies, this paper used unit record data to estimate the effects of outside incomes, demand for labour, workers' relative bargaining strength and category of wage contract on nominal wage changes.

The remaining parts of this paper tests important influences on wage changes using a general bargaining model of wages. Section 2 summaries the characteristics of the wage setting process in Australia. Section 3 overview theories of wage determination, section 4 discusses factors which influence the firms' preferred wage and section 5 discusses the determinants of the workers' desired wage. Section 6 describes the data and finally section 7 tests the general bargaining model using cross-sectional individual data from the Melbourne Institute's telephone survey from the period August 1997 to August 2000.

\footnotetext{
${ }^{2}$ Macroeconomics studies of the determination of aggregate wages are more common. See Fels and Tran (1981), Kirby (1981), Trivedi and Rayner (1978) and additional Phillips Curve estimations for macroeconomic models.

${ }^{3}$ The enduring significance of industry wage differentials in Australia and the USA (see Borland and Suen 1990 p. 36) is largely unexplained by the literature. Empirical tests have failed to distinguish whether it has arisen from correlations between unobservable characteristics of workers and their industry (driven by competitive forces) or non-competitive rent-seeking behaviours by workers or unions.
} 


\section{Current issues in the Australian wage setting environment}

Apart from questions of enduring academic interest, knowing the determinants of wage changes has relevance to two contemporary features of the labour market: the dispersion of earnings and the shift toward workplace wage bargaining.

With respect to the first issue, several countries including Australia, have recorded widening distributions of earnings since the early 1980s (see King et al. 1992, Gregory and Vella 1995, Borland and Wilkins 1996). ${ }^{4}$ Variations in Australian occupational wage inequalities have been recorded since 1914 with notable peaks in inequality just after the First World War, early in the Depression and the late 1940s (see Hancock and Moore 1972). ${ }^{5}$ Suggested causes of these shifts, then and now, include market forces which are reflecting substantive changes in demand or supply, changes to the power of institutions, such as unions, and changes to social mores brought about through prolonged periods of full or less than full employment. While Hancock and Moore 1972 believed that '...preconceived notions of secular trend or stability should be eschewed' ( $p$ 109), contemporary researchers are more inclined to search for systemic or underlying causal relationships. ${ }^{6}$

The second current issue concerns the effects of decentralisation of wage setting since 1987. From 1983 to 1987 a highly centralised system of wage determination which imposed limits on the type and extent of microeconomic wage increases operated. ${ }^{7}$ Some

\footnotetext{
${ }^{4}$ This trend has been noticed in Australia since 1979 but lack of earlier data does not allow us to rule out the possibility that the process was well in train before then. Inequality was on the rise during the late 1960s, when the study by Hancock and Moore 1972 concluded.

${ }^{5}$ Occupational wage variations studies are not strictly the same as earnings dispersion studies as the former consider only difference in the paid rates and not the number of workers who are entitled to each rate of pay.

${ }^{6}$ See for example Howell \& Wolff (1991), Gregory 1993, Spenner 1995, Borland 1996, Webster 1998.

${ }^{7}$ The Australian Industrial Relations Commission (AIRC) was only permitted to certify or award microeconomic wage (up to a fixed amount) increases that lead to productivity increases. Informal wage variations were always allowed but many
} 
decentralisation of this system was proposed and widely accepted in the late 1980s as it was thought to be a precursor for more trade offs between higher pay and inefficient work practices. While informal enterprise level bargaining has always been conducted in Austrlaia, it was felt that the existence of extensive extra-firm bargaining apparatuses allowed workplaces to free-ride and consequently shirk important industrial communications that are needed for efficient workplace organisation.

Comprehensive national wage increases ceased in 1993 with general increases being confined to awards - the safety net - covering at that time about one third of employees. The course of promoting workplace level negotiations and reducing workers' bargaining power was furthered by the change in Federal Government in 1996 and the subsequent passage of the new governments industrial relations Act. Many aspects of this Act were however not supported by the earlier union and academic supporters of decentralisation.

Advocates of these post-1996 attempts to decentralise and deregulate the wage setting system argue that its main benefits stem from both its heterogeneous treatment of wages and its ability to augment employer bargaining power. ${ }^{8}$ Four types of benefits are possible but these are not always mutually compatible. First, shifting negotiations back into the enterprise is thought to encourage 'Employee Involvement' models of workplace governance. This mode of management, which emphasises trust, loyalty and mutual commitment to the goals of the firms, is conducive to workplace trade-offs between productivity and wage rises. There is some empirical evidence that this type of governance is associated with more efficient workplaces (see Fernie and Metcalf 1995). Second, by allowing wages to respond more freely to market forces, a decentralised system is thought to encourage a more efficient

\footnotetext{
employers who held 'rise and fall' clauses in their product market contracts desired the increment to be embedded in legal awards.

${ }^{8}$ Support for some level of decentralisation came from both Labour and Coalition federal Governments, major industry groups and the peak trade unions council (see Tseng and Wooden forthcoming).
} 
allocation of labour across locations, occupations and industries. ${ }^{9}$ Third, decentralisation may encourage both the firm and workers to invest more heavily in training if wage-training trade-offs are permitted for more classifications of labour. ${ }^{10}$ Finally, by shifting the locus of bargaining from the nation or industry to the workplace or the individual, workers' power is fragmented and weakened less capacity exists for collective action and negotiation. Costpush factors in wage inflation may be constrained and the pecuniary incentive for hiring more workers may rise. Most of the public debate in Australia during the 1990s centred on the first type of benefit.

Sceptics of these reforms essentially argue these effects are uncertain simply because the 'unregulated' labour market will operate less like a 'perfect market' and more like either a series of monopsonies or bilateral monopolies (King 1997, Stegman 1999). The prevalence of imperfect knowledge, heterogeneous jobs and firm-specific skills across labour markets makes most labour markets 'imperfect'. Monopsonies classically generate sub-optimal wageemployment outcomes and bilateral monopolies do not usually give determinant economic outcomes. ${ }^{11}$ Accordingly, scope exists for non-economic factors such as the bargaining power of incumbent workers to influence the wage outcome and to the extent this varies across the economy, wage inequalities will be amplified and a US style 'working poor' class will emerge (Dabscheck 1997, Campbell and Brosnan 1999, p 375). If workers' notions of justice and fairness are disregarded, a generalised outbreak in wages could eventually erupt. Some commentators believe that general use of individualised contracts may merely drive

\footnotetext{
${ }^{9}$ That is, the wages are correlated with the net marginal (revenue) product of labour.

${ }^{10}$ Accordingly wages will be less than the value of the marginal product of labour by an the amount of training costs in the case of firm-general training. The situation for firm-specific training is more complex and depends on both parties estimation of employment tenure with the firm.

${ }^{11}$ However, in term of training outcomes, monopsonies may be more efficient as it raises the firms ability to appropriate benefits from training.
} 
mistrust and conflict underground producing an opposite result from the employee involvement type of governance (Hamberger 1995). Adjustments to wage rates, the introduction of new technologies and extensions to training are best achieved under incomes policies where every-one feels confident of a just and equal treatment vis-à-vis their peers. ${ }^{12}$

If decentralisation has the effects claimed by its proponents, then wages rates will become more aligned with individual or plant-based worker productivity and more responsive to external market forces. If, on the other hand, the critics are correct, then wages will become more responsive to the individual or the group's bargaining power. ${ }^{13}$ However, these tendencies can become blurred both theoretically and empirically because market forces underpin bargaining power to some extent.

Unfortunately, the data used for this study only covers the period 1997 to 2000 and it cannot indicate which path decentralisation has followed because of the difficulties with establishing the counterfactual. Nevertheless, the general thrust of the arguments suggest that if the advocates are correct, then wage changes during 1997 to 2000 should become more sensitive to market forces compared with the 1980s. If the critics are correct, then wage changes will be more sensitive to bargaining forces. A more comprehensive test of these hypotheses should also include additional factors such as variation in production market competition.

\footnotetext{
${ }^{12}$ Adherents of this view do not ascribe real and relative wages a major role in determining either employment growth, productivity growth or the efficient allocation of labour (Stegman 1997, King 1997)

${ }^{13}$ A more subtle argument maintains that the outcome depends on the union context. Dowrick 1993, for example, argues by deduction that decentralisation of bargaining will lead to greater wage pressures and inequalities if industry or craft level unions prevail as the discipline from product market competition is less. Accordingly the external product market has a less punitive force on higher costs of production compared with wage rises negotiated at the firm level. Alternatively, nationally negotiated wages internalise the effects on inflation, central bank action and/or employment.
} 
In order to test for the empirical significance of potential determinants of wage changes, a simple model of wage determination is required. The following three sections outline the model underpinning the estimations undertaken in section 7.

\section{Theories of wage determination}

The theories for why wages change are a corollary of the theories of wage rate determination. Two basic models exist: first, the competitive market model, which asserts that wages will naturally converge to a market clearing level unless impeded by regulations and second, a bargaining model. In the former, wage changes arise either from a movement in the clearing rate due to a fundamental shift in the market parameters (such as productivity growth, changes in the supply of labour and shifting demand for the product) or from the disequilibrium process of shifting towards the market clearing rate. Labour markets experiencing excess demand will incur wage rises and markets experiencing excess supply will incur wage falls given the level of inflationary expectations and underlying growth in labour productivity. In aggregate, real wages will only grow faster than productivity growth if there is over full employment, unless one appends theories of asymmetrical adjustment and so on. For this reason, this type of theory has not proven popular during periods of high sustained levels of aggregate unemployment and rising real wages.

Bargaining theories, by contrast, exude a more plausible resonance. These models assume that wages are settled as some point between workers' desired wage rate and alternative incomes and firms' desired wage rate. The relative bargaining power of the parties determine the final position between the two market driven desired wage rates. This wage outcome can be formally modelled as a Nash bargain ${ }^{14}$, or as a simple weighted average of the two polar positions such as Cartter's costs of agreeing and disagreeing 
model. ${ }^{15}$ Ultimately, it does not matter for estimation purposes which model is assumed because the independent variables in the estimated wage equation are the same.

The Cartter style general bargaining model is used in this paper because it is conceptually more straight forward. In real life, wage negotiations are a series of interrelated bargaining situations undertaken in the context of behavioural uncertainty and infinite possible strategies and outcomes. The Nash bargaining model characterises this as a closed set optimising problem; a reduction many theoreticians regard as inappropriate. The Cartter model avoids these criticisms of pseudo-rigour by making no pretence of deductive precision.

The Cartter model requires a definition of the firms preferred wage, the workers' preferred wage and a set of relative bargaining power variables.

\section{The firm's preferred wage}

In common with other inputs to the production process, firms seek to minimise the price paid for labour subject to available supply. However, in the case of labour inputs, these calculations are overlaid by considerations which arise from the behavioural and social attributes of labour. Buyers and sellers do not necessarily stand in a direct antithetical relationship in the labour market as they do in commodity markets for they often share common interests against the consumer (Hieser 1970, p. 57). Firms generally invest in their workforce and the wage acts not only as a cost of production but as a means of retaining labour and thus re-couping this investment. These investments are not a trivial concern to the firm. Accumulated workforce skills and the organisation of the workplace are integral to its competitive advantage. The firm needs a certain core workforce to pass on tacit skills and

\footnotetext{
${ }^{14}$ Blanchflower and Oswald 1994, Nickell et al. 1994, Mumford and Dowrick 1994, Nickell and Kong 1992, Creedy and McDonald 1991, Blanchflower et al. 1990.

${ }^{15}$ Cartter 1959 Ch 9 . Hieser 1970 also has a bargaining model.
} 
knowledge to newcomers and it will incur abnormal costs if attrition rates are high and the informal skill transfer process is disrupted. (Marshall 1890 p 255-66, 271, Young 1928, Loasby 1983, Porter 1990, Ch 1, Best 1990, p 16, 38-41, 331).

Given this, firms may voluntarily agree to above market wages to prevent undue loss of higher quality workers, to keep attracting high quality applicants and to sustain morale, training commitment and work effort at optimal levels within the firm. ${ }^{16}$ Late $20^{\text {th }}$ century literature refers to this phenomenon as 'efficiency wage' effects although the concepts had been long since accepted well before the term was coined.

From the workers' point of view, jobs vary in terms of the career prospects and opportunities for learning. If fully productive staff need to be (at least partly) trained within the firm, then there are limitations to the rate at which the firm can expand over time and a kink arises in the short run labour supply curve. On both these accounts, a monopsonistic model is a more general model of the labour market and the firm's long run supply of labour has a positive slope.

In terms of a specific model, turnover costs and labour heterogeneity can create a gap between the minimum supply price of the incumbent workforce and the maximum wage the firm is prepared to pay at the current level of employment. In the stylised example below, the supply of ready skilled and experienced labour is not perfectly elastic because the pool of suitable people is limited.

It is not possible to derive first-order conditions from general objective functions that are specific enough for an estimation exercise based on these premises. To obtain therefore a reduced from equation necessary for estimation purposes, either we can assume that these equations are solvable in terms of their parameters (i.e. Calmfors and Forslund 1991) or

\footnotetext{
${ }^{16}$ A USA survey of over 300 business people in the early 1990s supported the view that firms will not cut pay because of the effects it has on worker morale (see Bewley 1998).
} 
define specific functional forms to allow us to identify which variables should be used for estimation purposes and the sign of the appropriate coefficient. While the latter route, which is used here, is more tractable, the functional choice clearly involves some arbitrary and expedient factors and any derived results should be taken as indicative and suggestive rather than literal. This method assumes that firms and workers both know and agree upon the same demand and supply functions; an assumption used to make the problem solvable rather than realistic. Despite these drawbacks, it is intended that the model contains the main forces which consciously or unconsciously determine that bargaining stances of the parties to the wage negotiating process.

Given this caveat, the firm's desired wage is the profit maximising wage given efficiency wage considerations in which the wage paid to workers affects this productivity ceteris paribus. Firms also have some monopsony power, for reasons discussed above, and the productiveness of labour is affected by the offered wage relative to outside incomes.

Efficiency wage considerations imply crudely that output is a function of wages realtive to outside incomes such that:

$$
q=f_{1}\left(A, l, \frac{w}{x}\right)
$$

Where $q$ is real output, $A$ is a variable which represents other inputs such as physical capital, workplace organisation, managerial efficiency, $l$ is units of labour, $w$ is the wage rate offered to workers in the firm and the term $x$ is the expected value of alternative incomes if workers pursued another activity. $x$ is the weighted average of all expected alternative sources of incomes (outside wages, unemployment benefits). $\beta$ and $\gamma$, which are positive fractions less than one such that $\beta>\gamma$, represent the sensitivity of production to labour inputs and efficiency wages respectively. 
Then the Marginal Revenue Product net of the costs to the other expenses of production and profits (net $M R P_{L}$ ) is the net Marginal Product times product price, $p$, ie

$$
n e t M R P_{l}=f_{2}\left(p, A, l, \frac{w}{x}\right)
$$

Let the minimum supply price of labour be represented as

$$
w=f_{3}(s, l, x)
$$

Where $s$ is the parameter of labour supply such that the larger $s$ the more inelastic labour supply and the higher must wages be to bring forth a supply of workers. It includes factors such as the outside wage, the level and accessibility of unemployment benefits and supply from the education, training and immigration sectors.

Maximising profits with respect to $w$ yields

$$
w=f_{4}(p, A, x, s)
$$

An increase in the sensitivity of production to either labour inputs or efficiency wages via the size of the coefficients in (4) will have a positive impact on the wage firms desire to offer. A rise in product demand (as encapsulated in $p$ ), the quantify of complementary inputs $(A)$, a rise in the inelasticity of labour $(s)$ and a rise in expected outside incomes $(x)$ will also increase the firms desire to offer higher wages. These effects have some ambiguity because a lower outside incomes lowers the inside wage needed to ensure a certain productivity of labour but also lowers the number of units of labour who are prepared to work for the said firm at every given wage rate. ${ }^{17}$

\footnotetext{
${ }^{17}$ In this specification there is no mathematical ambiguity as $1-\gamma$ is positive. This stems from the simplifying assumption that $x$ is raised to the power of one in the labour supply function.
} 


\section{The workers' preferred wage}

The workers' desired wage is represented by a group utility maximisation function subject to the labour demand curve constraint. Workers combine to extract some of the above normal profits arising from product market power. In individual contracts the group becomes the individual. These individuals can still hold some monopoly power if they posses unique or scarce skills. The workers' collective welfare function is usually given as (i.e. Blanchflower and Oswald 1994)

$$
V=l\left(v-x^{*}\right)
$$

where $V$ represents workers' total utility from working in their given job, $v$ represents the workers' utility and $v^{*}$ is expected utility of non-working states. The workers' desired wage is derived by maximising (5) subject to the wage-employment trade-off implied by the firm's (or industry's or occupation's) demand curve (2).

Conventionally, outside wages, the level of unemployment benefits and the relative probabilities of each state are the major determinants of $v^{*}$.

Accordingly, assume that $v=w$ and

$$
v^{*}=x^{18}
$$

Assume workers' maximise

$$
V=l[w-x]
$$

subject to a demand for labour function (2).

Maximising with respect to $w$ defines a desired worker wage, $w_{w}$ (in logs)

$$
w_{w}=f_{5}(x) \text {. }
$$

\footnotetext{
${ }^{18}$ Strictly, the disutility of working or being in each state should also be included.
} 
This suggests that workers desired wage is set with respect to outside incomes $(x)$ and the labour input and the efficiency wage parameters.

\section{The bargained wage outcome}

If the representative firm and workers (or their industry or national agents) set their preferred wage rates according to this model, then the remaining task is to determine how any difference of position will be resolved. The general model discussed in the introduction assumes that the final outcome, $w_{b}$, depends upon the outcome of the costs of agreeing and disagreeing of the two parties (see for example Cartter 1959, Ch 9) or the balance of bargaining power between the two groups, such that

$$
w_{b}=(1-\theta)\left(w_{w}\right)+\theta\left(w_{f}\right)
$$

where $\theta$ represents the relative bargaining expertise and power of labour relative to capital.

In this case, $\theta$, represents the net utility gain to firms of $w_{f}$ relative to $w_{w}$ and the costs they must bear in order to achieve this agreement relative to the net gains to workers of $w_{w}$ relative to $w_{f}$ plus the costs it must bear in order to achieve it.

Under the general bargaining model, the final wage outcome, $w_{b}$, as a simple weighted average of the firm's desired wage (5) and the workers' desired wages (11), thus:

$$
w_{b}=f_{6}(\theta, p, A, x, s)
$$

Differentiating with respect to time approximates to

$$
\dot{w}_{b}=\varphi_{1} \dot{p}+\varphi_{2} \dot{A}+\varphi_{3} \dot{x}+\varphi_{4} \dot{s}+\text { constant }
$$

$\varphi$ includes among other factors the relative bargaining strengths of the two parties. Prices and incomes are defined in nominal terms and the effect of in(de)flation would be to shift the parameters of all parties right (left) and thus the expected inflation rate, $\dot{p}^{e}$, can be added to the final equation. 
In this simplified example, the bargained wage outcome is a function of the parameters of the labour supply function $(\dot{x}, \dot{s})$, the parameters of the demand function $(p, \dot{A}, \dot{x})$, the parameters of the utility function $(\dot{x})$ and the determinants of the bargaining coefficient $\varphi-$ in addition to the expected inflation rate.

These parameters share common independent factors and during the estimation process it is often not possible to distinguish demand side influences from supply side influences. A stronger local economy or market will affect both demand for labour, and via competition, the firm's labour supply. An individual's characteristics may act as empirical proxies for alternative incomes, the shape of their utility function, their inherent productivity or their groups or individual bargaining power. Some groups of workers such as part-time workers may be less organised as their job is not their main activity. Men may be more militant than women. People with higher qualifications may be in jobs where the earnings profiles are steeper because of higher returns to work experience. However, an experience premium may also account for differences between the sexes and full-time and part-time workers. A greater scope for workers to enter individual, enterprise or national bargaining groups may increase the dispersion of bargaining power across individuals, but a wage setting framework which encourages wage : productivity trade-offs may also lower the firm's cost function.

\section{The data}

While it is not possible to test the relative effects of basic demand or supply or bargaining factors on wage changes, it is possible to test for their sensitivity to some of the proxy variables mentioned above. The data set which is derived from the Melbourne Institute Wages Survey includes individual unit records on individuals' characteristics such as age, sex, educational attainment, part-time or full-time status, wage determination category. To this has been added four other time related variables: days lost through industrial disputes, 
occupation or location specific vacancy and employment measures and individual specific estimates of unemployment benefits and rent allowance. Unfortunately data on changes to demand side firm level characteristics such as industry, technology, firm organisation and management and supply side variables such as the individual's personal characteristics, occupational experience and job related training were not available

The original data used in the estimation process has been collected by telephone survey and covers 1200 randomly selected householders each quarter between August 1997 and May 2000. Only employees who have been in the same job for over a year are included in our wages sub-sample. This nets about 450 people each survey period. While attempts have been made to obtain unbiased information from the population, several biases still exist in the recorded data. Surveys of employees generally find that respondents understate their wages and non-wage benefits compared with firms based surveys. On the other hand, jobs which offer small wage rises are likely to have high rates of attrition, and will be selected out of our survey as only people which have been in the same job for over a year were interviewed. $^{19}$

The dependent variable, $\dot{w}$, is represented by individual's reported change in their total wage rate over the last 12 months. After adjusting for changes to their hours of work, this is the closest available estimate for the change to the hourly nominal wage rate. The change in outside incomes, $\dot{x}$, is represented by both a change to unemployment benefits and rent allowance (these are based on the person, family composition, rental status and time period), the individual's level of educational attainment and their age. Education and age act as proxies for wage changes they would receive in another job.

Changes to $p A$, which literally depicts demand for the firm's output and productivity arising from non-wage labour inputs, will be reflected in a rightward shift in the demand for

\footnotetext{
${ }^{19}$ A disproportionate number of workers who changed jobs over the year are under 24 years of age.
} 
labour function and a growth in job vacancies and employment ceteris paribus. The difficulty of obtaining exogenous measures of labour demand and supply parameters has meant that lagged labour market measures such as the changes in vacancies and employment were used. Time-related vacancies associated with the individual's occupation and state of residence (in the case of professionals, para or associate professions and tradespeople) and general vacancies (for other occupations) have been assigned to each unit record. Time, sex, age and location specific employment data have been assigned to each individual record as well. Eighty three geographic regions have been used. Vacancy and employment data has been converted into a year on year percentage changes and lagged by six months to avoid endogeneity and to reflect the time lag between when wage negotiation are undertaken and when wage change are implemented. While these are the best available measures of the degree of demand for worker in our sample, they still remain crude proxies. Because of the prevalence of 'market imperfections' (referred to in section 4 above), specific firm characteristics and individual work history information would have been included here if available.

Workers' relative bargaining strength, $\varphi$, is represented by the number of days work lost through disputes over wages across the whole economy. It is not specific to the individual's occupation or industry. ${ }^{20}$ Use of this variable assumes that unions only call or seek to continue a strike over wages if they believe that their bargaining power is strong

\footnotetext{
${ }^{20}$ Using union density for each industry is not available proxy. Union density data is too infrequent (biennial) for our purpose and there has been a change in industry classification over the period of time under consideration. No concordance was produced.
} 
enough on balance to deliver them a positive outcome. ${ }^{21}$ In addition, sex and part-time status variables may also reflect the individual's bargaining strength.

The type of employment contract the worker is employed under may influence his or her bargaining strength or be an indicator of prior bargaining strength. Alternatively, workers employed under individual contracts or enterprise agreements may have achieved higher wage rises because they are negotiating wage-productivity trade-offs with employers. The data distinguish four types of contracts: individual contracts, enterprise bargains, awards/safety net provisions, and 'others'. The latter includes very casual or verbal agreements. The percentage breakdown shown in Table 1 indicates that just under a quarter of employees in our data set are on individual contracts, one third are employed on enterprise agreements, a further third remained on their old awards and about 5 per cent have some other form of agreement. Three per cent did not know the form of employment contract.

${ }^{21}$ Since the mid-1980s, the correlation coefficient between days lost though disputes over wages and the employment : population ratio is about 0.5 . This suggests that strikes over wages are more likely when the labour market is tight and worker power is relatively strong. 
Table 1. Percentage distribution of employees (in current job for over 12 months) by employment contract type, August 1997 to August 2000, Australia

\begin{tabular}{lc} 
Employment contract type & Percentage \\
\hline Individual contract & 23.1 \\
Enterprise agreement & 33.6 \\
Award/safety net & 35.1 \\
Other & 5.0 \\
Don't know & 3.1 \\
TOTAL & 100 \\
\hline
\end{tabular}

Time appropriate measures of the individual's price expectations do not exist. Only a person's current inflationary expectations are include in the survey but it is acknowledged that these are a (poor) proxy for their expectations over the prior year.

All data are quarterly and have been derived from telephone survey except for employment data (AUSSTATS), vacancy data (DEWRSB and AUSSTATS), industrial disputes data (AUSSTATS), unemployment benefits and rent allowance (FaCS).

\section{Econometric model and estimation results}

Equation (15) has been estimated via several methods - OLS, ordered probit and multinomial logit. Ideally, $\dot{w}$ could be treated as continuous variable and perform OLS estimation. However, the distribution of reported wage changes by respondents suggests digit preferencing, that is respondents answers are biased towards common digits such as 0,5 , and 10 (see Tseng 2000). Categorising the data into several groups is a way to make the dependent variable less sensitive to recall error and digit preferencing. Total pay changes are grouped into 6 categories, less than zero, zero, 0-3 per cent, 3-6 per cent (including 3 per cent), 6-9 per cent (including 6 per cent), 9 per cent and above.

While the dependent variable is ordered, an ordered probit estimation is not the preferred econometric model because it assumes that the effects of independent variables are the same for the comparison between any two consecutive categories. However, Tseng (2000) shows that workers on individual contract are more likely to have either large pay 
increases or no pay changes, while workers on enterprise agreement are more likely to have received small pay increases. In this case, the relationship between pay determinants and the ordered pay-change categories is not monotonic. It is not correct to assume that workers on individual contracts are more likely to have larger wage growth, nor that enterprise agreement workers gain higher wage increases. Similarly, young workers are more likely to have large pay increase, but they are also more likely to have wage cut. This implies that the parallel regression assumption underlying ordered probit model may not be appropriate. The score (or LM) test statistic, which tests for whether this assumption is violated, supports the hypothesis that coefficients are not equal across categories. ${ }^{22}$

The final estimation applies the multinomial logit model, which can be regarded as simultaneously estimating binary logits for all possible comparisons among the outcome categories. The model is as follows:

$$
\begin{aligned}
& \operatorname{Pr}(Y=j)=\frac{\exp \left(x_{i} \beta_{j}\right)}{1+\sum_{k=1}^{J} \exp \left(x_{i} \beta_{k}\right)}, \text { for } j=1,2, \ldots J \\
& \operatorname{Pr}(Y=0)=\frac{1}{1+\sum_{k=1}^{J} \exp \left(x_{i} \beta_{k}\right)}, \text { for } j=0
\end{aligned}
$$

The results for multinomial logit using the pay decrease category as base group $(Y=0)$ are presented in the appendix. Only employees who had been in the same job, working the same normla hours per week have been included in the empritical analysis. Two sets of results are included, one for all employees described above (Table A1) and the other for all workers except those who said that their wages had not changed (Table A2). The later has been excluded as it is possible that some respondents who claim that their wages were the same as 12 months earlier, had interpreted this as 'the same rate of increase as previously'. This error

\footnotetext{
${ }^{22}$ LM statistic =194.83, 68 df, see Long (1997).
} 
are less likely to occur for those who reported a change in their total pay since further question on percentage change are asked.

The correct predictions performance indicator shows that the mulitnomial regression method nearly doubles the explanatory power of the equation over and above random assignment. The percentage of cases that would be correctly predicted with random assignment is 23.0 , but with all variables, the estimated mulitnomial logit estimates 39.9 per cent correctly. Dropping the insignificant variables of time, unemployment benefits, rent allowance reduces this to 39.3 per cent.

Marginal effects of independent variables are presented in the tables below. For continuous variables, the marginally effects are defined as the differences of probabilities if the independent variable change from one standard deviation below mean to one standard deviation above mean keeping other variables constant. The marginal effects for discrete variables are based on the comparison of probabilities between categories. Column 2 presents the marginal effects from the estimation for all workers and column 3 excludes those whose total pay remain unchanged. As can be seen from the following tables, the results in column 3 are generally similar but larger than column 2, which support our view on the possible misinterpretation of zero pay changes by respondents.

As the results below show, most of the measurable independent variables display a reasonable level of significance. ${ }^{23}$ The variables for government transfer payments and price expectations were not found to have any significant effects on nominal wage changes and are hence for the excluded from the discussion. However, of the remaining significant variables, variation in the independent variables were found to only have a relatively small impact on the nominal wage outcomes for each individual. Major missing variables in the specific

\footnotetext{
${ }^{23}$ This means that the coefficient was significant at the 5 or 10 per cent level and displayed the correct sign in the ordered probit equation. Assessing significant in the multinomial is more difficult.
} 
equation arising from changes to demand side firm level characterises such as technology, firm organisation and management ${ }^{24}$ and supply side variables such as the individual's personal characteristics, occupational experience and job related training. In addition, some wage changes will be due to non-systematic random effects. However, part of the low explanatory power of the econometric equations, may be due to the quality of the dependent variable data. Recorded nominal wage changes are based on workers' re-call evidence and to the extent that respondents do not remember accurately changes to their pay there will be an unexplained error in the data. As mentioned above, employee surveys under report the extent of wage changes.

Education and age are the main supply side variables in our equation. Table 2 and 4 present the marginal effects of different levels of education and age on the probability of being in each wage change category. As the results are very similar for both samples of employees, the discussion refers to all employees (column 2). The probability of achieving a wage rise is significantly related to both education and age. Workers with only a year 10 educational attainment are more likely to receive a pay cuts or no pay change and less likely to receive higher pay rises that people with post-graduate education. Being aged 18 to 24 makes the worker considerably more likely to receive either a pay cut or pay rises over 6 per cent compared with workers aged 50 to 54 years.

\footnotetext{
${ }^{24}$ These may be captured in an industry variable.
} 
Table 2. Marginal effect of year 10 education versus post-graduate education on the probability of achieving each wage outcome

\begin{tabular}{lrr}
\hline \% Annual wage change & $\begin{array}{c}\text { All employees in same } \\
\text { job whose hours had } \\
\text { not changed }\end{array}$ & Exclude 'same' \\
\hline Negative & 0.015 & 0.052 \\
Zero & 0.168 & \\
Positive but under 3 & -0.020 & 0.026 \\
3 to under 6 & -0.049 & 0.012 \\
6 to under 9 & -0.039 & -0.035 \\
9 and over & -0.074 & -0.056 \\
$\mathrm{~N}$ & 3270 & 2128 \\
\hline
\end{tabular}

Method: Multinomial Logit

Table 3. Marginal effect of being age 18 to 24 years versus 50 to 54 years of age on the probability of achieving each wage outcome

\begin{tabular}{lrr}
\hline \% Annual wage change & $\begin{array}{c}\text { All employees in same } \\
\text { job whose hours had } \\
\text { not changed }\end{array}$ & Exclude 'same' \\
\hline Negative & 0.012 & -0.008 \\
Zero & -0.162 & \\
Positive but under 3 & -0.014 & -0.072 \\
3 to under 6 & -0.018 & -0.120 \\
6 to under 9 & 0.039 & 0.039 \\
9 and over & 0.143 & 0.162 \\
$\mathrm{n}$ & 3270 & 2128 \\
\hline Method: Multinomial Logit & &
\end{tabular}

Labour demand variables were also found to be significant and generally exhibited the correct a priori sign. However the significant of the variable was sensitive to how they were difference and the choice of specific data. For example, the age/sex/region specific employment measure was found to be significant but the sex/full-time and part-time/region specific measure was not. Nonetheless, the ultimate chosen measures were consistently significant at either the 5 or 10 per cent level. Table 4, which presents an evaluation of the coefficients, shows that when vacancy growth is one standard deviation below the mean rather than one standard deviation above the mean, a worker is more likely to get a wage cut. Similarly, when the local employment growth is one standard deviation below the mean compared with one standard deviation above the mean, a worker is also more likely to get a wage cut, ceteris paribus (Table 5). It is possible that these wage cuts affected bonuses and over time rather than the workers base pay (see Tseng 2000). While labour market pressures 
appear to affect the probability of the individual incurring a wage reduction, they have little systematic effect of the size of any non-negative wage changes.

Table 4. Marginal effect of being in an occupation/state where percentage change in vacancies (lagged 6 months) are one standard deviation below mean versus one standard deviation above the mean on the probability of achieving each wage outcome

\begin{tabular}{|c|c|c|}
\hline$\%$ Annual wage change & $\begin{array}{c}\text { All employees in same } \\
\text { job whose hours had } \\
\text { not changed }\end{array}$ & Exclude 'same' \\
\hline Negative & 0.013 & 0.024 \\
\hline Zero & 0.007 & \\
\hline Positive but under 3 & -0.011 & -0.012 \\
\hline 3 to under 6 & 0.002 & 0.003 \\
\hline 6 to under 9 & 0.000 & 0.003 \\
\hline 9 and over & -0.011 & -0.017 \\
\hline $\mathrm{n}$ & 3270 & 2128 \\
\hline
\end{tabular}

Table 5. Marginal effect of living in a statistical region where percentage change in age and sex relevant employment (lagged 6 months) is one standard deviation below mean versus one standard deviation above the mean on the probability of achieving each wage outcome

\begin{tabular}{lrr}
\hline \% Annual wage change & $\begin{array}{c}\text { All employees in same } \\
\text { job whose hours had } \\
\text { not changed }\end{array}$ & Exclude 'same' \\
\hline Negative & 0.021 & 0.032 \\
Zero & -0.001 & \\
Positive but under 3 & -0.009 & -0.004 \\
3 to under 6 & -0.002 & -0.004 \\
6 to under 9 & 0.001 & 0.000 \\
9 and over & -0.014 & -0.025 \\
\hline N & 3270 & 2128 \\
\hline
\end{tabular}

Method: Multinomial Logit

The type of employment contract under which a person is employed is associated with a large effect on the marginal probability of specific wage outcomes. According to Table 6, being employed under an individual contract rather than an award makes the worker more likely to receive no wage change or a rise of over 6 per cent rather that a pay cut or a rise below 6 per cent. This bi-modality in individual contracts may arise because wages are negotiated less regularly than the annual safety net adjustment or because there are two distinct types of workers on individual contracts, those with very weak bargaining power and 
those with very strong power (due perhapd to scarce skills). Being employed under an enterprise bargain rather than an award makes a worker more likely to receive pay rises between 1 to under 9 per cent and less likely to receive pay cuts, no pay change or a pay rise over 9 per cent (Table 7).

Table 6. Marginal effect of being employed under an individual contract versus an award (safety net) on the probability of achieving each wage outcome

\begin{tabular}{|c|c|c|}
\hline \% Annual wage change & $\begin{array}{c}\text { All employees in same } \\
\text { job whose hours had not } \\
\text { changed }\end{array}$ & Exclude 'same' \\
\hline Negative & -0.013 & -0.015 \\
\hline Zero & 0.025 & \\
\hline Positive but under 3 & -0.077 & -0.125 \\
\hline 3 to under 6 & -0.027 & -0.032 \\
\hline 6 to under 9 & 0.023 & 0.042 \\
\hline 9 and over & 0.069 & 0.130 \\
\hline $\mathrm{n}$ & 3270 & 2128 \\
\hline
\end{tabular}

Method: Multinomial Logit

Table 7. Marginal effect of being employed under an enterprise agreement versus and award (safety net) on the probability of achieving each wage outcome

\begin{tabular}{|c|c|c|}
\hline \% Annual wage change & $\begin{array}{c}\text { All employees in same } \\
\text { job whose hours had not } \\
\text { changed }\end{array}$ & Exclude 'same' \\
\hline Negative & -0.001 & -0.037 \\
\hline Zero & -0.213 & \\
\hline Positive but under 3 & 0.171 & 0.139 \\
\hline 3 to under 6 & 0.082 & -0.001 \\
\hline 6 to under 9 & 0.016 & 0.007 \\
\hline 9 and over & -0.055 & -0.109 \\
\hline $\mathrm{n}$ & 3270 & 2128 \\
\hline
\end{tabular}

Method: Multinomial Logit

The remaining 'bargaining' related variables were also significant. Being male made one more likely on average to have been awarded either no pay rise or a rise of over 6 per cent (Table 8), being employed part-time was strongly associated with lower pay rises and more pay cuts (Table 9) and pay changes across the whole economy were generally smaller when the number of days lost through wage dispute were lower (Table 10). 
Table 8. Marginal effect of being male versus female on the probability of achieving each wage outcome

\begin{tabular}{lrr}
\hline \% Annual wage change & $\begin{array}{c}\text { All employees in same } \\
\text { job whose hours had } \\
\text { not changed }\end{array}$ & Exclude 'same' \\
\hline Negative & -0.013 & -0.023 \\
Zero & 0.010 & \\
Positive but under 3 & -0.014 & -0.017 \\
3 to under 6 & -0.018 & -0.020 \\
6 to under 9 & 0.019 & 0.032 \\
9 and over & 0.017 & 0.027 \\
$\mathrm{n}$ & 3270 & 2128 \\
\hline
\end{tabular}

Method: Multinomial Logit

Table 9. Marginal effect of being employed part-time versus full-time on the probability of achieving each wage outcome

\begin{tabular}{lrr}
\hline \% Annual wage change & $\begin{array}{c}\text { All employees in same } \\
\text { job whose hours had } \\
\text { not changed }\end{array}$ & Exclude 'same' \\
\hline Negative & 0.013 & 0.037 \\
Zero & 0.067 & \\
Positive but under 3 & 0.019 & 0.058 \\
3 to under 6 & -0.084 & -0.099 \\
6 to under 9 & -0.007 & -0.033 \\
9 and over & -0.009 & 0.007 \\
\hline n & 3270 & 2128 \\
\hline Method: Multinomial Logit & &
\end{tabular}

Table 10. Marginal effect of wage dispute being one standard deviation below mean versus one standard deviation above the mean on the probability of achieving each wage outcome

\begin{tabular}{lrr}
\hline \% Annual wage change & $\begin{array}{c}\text { All employees in same } \\
\text { job whose hours had } \\
\text { not changed }\end{array}$ & Exclude 'same' \\
\hline Negative & 0.011 & 0.020 \\
Zero & 0.010 & -0.019 \\
Positive but under 3 & -0.015 & 0.017 \\
3 to under 6 & 0.009 & 0.003 \\
6 to under 9 & 0.000 & -0.021 \\
9 and over & -0.016 & 2128 \\
\hline $\mathrm{n}$ & 3270 &
\end{tabular}

\section{Implications for the economy}

As discussed in the introduction, nominal wage changes have a profound effect on (original) income distribution and can have important allocative and macroeconomic functions in the economy as well. With respect to incomes distribution, data presented in Table 11 reveals that relative wage increases are positively correlated with broad measures of individual 
economic well-being. With only one exception, higher wages growth are attributable to individuals from higher income households. In addition, individuals receiving higher wage increases are more likely to come from more advantaged local areas. Respondents have been classified according to the level of socio-economic disadvantage and advantage of their local (postcode) area of residence. As shown in Table 12 and 13, the lower the level of wage increase the greater the level of disadvantage. The same pattern occurs among the indexes of advantage. Higher wage change groups come on average from more advantaged postcode areas.

According to the adherents of decentralised wage systems, wages since the mid 1990s should be more sensitive to labour market pressures than during the 1980s. However, the analysis from the Melbourne Institute wages survey has found that while wage changes are affected

Table 11: Average household incomes by annual nominal wage change*

\begin{tabular}{lccr} 
& Annual household income \$ & \\
\hline $\begin{array}{l}\text { \% Annual wage } \\
\text { change }\end{array}$ & Mean & Std. Dev. & Sample size \\
\hline $\begin{array}{l}\text { Negative } \\
\text { Zero }\end{array}$ & 55769 & 34381 & 390 \\
Positive but under & 60957 & 36502 & 1410 \\
3 & 61484 & 35036 & 522 \\
3 to under 6 & 68761 & 37073 & 993 \\
6 to under 9 & 78813 & 42479 & 198 \\
9 and over & 73503 & 43250 & 548 \\
\hline Total & 64998 & 38033 & 4061 \\
\hline
\end{tabular}

Note: Twenty five per cent of respondents did not give their income. It has been assumed that the average income of households indicating that their incomes was over $\$ 100000$ is $\$ 150000$. 
Table 12: Average 1996 Socio-economic index of disadvantage in of area by annual nominal wage change

\begin{tabular}{lccr}
\multicolumn{2}{c}{$\begin{array}{c}\text { 1996 Socio-economic index of } \\
\text { disadvantage }\end{array}$} & Std. Dev. & Sample size \\
\hline $\begin{array}{l}\text { \% Annual wage } \\
\text { change }\end{array}$ & Mean & 69.8 & 499 \\
\hline $\begin{array}{l}\text { Negative } \\
\text { Zero }\end{array}$ & 1011.4 & 72.3 & 1709 \\
$\begin{array}{l}\text { Positive but under } \\
3\end{array}$ & 1013.8 & 71.1 & 605 \\
3 to under 6 & 1016.2 & & 1123 \\
6 to under 9 & 1017.1 & 69.5 & 209 \\
9 and over & 1022.5 & 66.1 & 632 \\
\hline Total & 1022.1 & 74.9 & 4777 \\
\hline
\end{tabular}

Notes: Based on the ABS Socio-economic indexes for areas (cat 2039.0). Indexes range from 800 to 1200 and an index of 1000 represents the median. The higher the index the smaller the proportion of disadvantaged residents in the postcode area of the respondent. 10.6 per cent of respondents could not be matched to a Socio-economic index in most cases because their postcode was not classified in 1996.

Table 13: Average 1996 Socio-economics index of advantage of area by annual nominal wage change

\begin{tabular}{lrrr}
\hline \multicolumn{4}{c}{ 1966 Socio-economic index of advantage } \\
\hline $\begin{array}{l}\text { \% Annual } \\
\text { change }\end{array}$ & Mean & Std. Dev. & Sample size \\
\hline $\begin{array}{l}\text { Negative } \\
\text { Zero }\end{array}$ & 999.7 & 77.8 & 499 \\
Positive but under & 1005.6 & 80.0 & 1709 \\
3 & 1006.7 & 79.8 & 605 \\
3 to under 6 & 1009.0 & 79.6 & 1123 \\
6 to under 9 & 1009.4 & 77.3 & 209 \\
9 and over & 1017.1 & 85.8 & 632 \\
\hline Total & 1007.6 & 80.4 & 4777 \\
\hline
\end{tabular}

Notes: Based on the ABS Socio-economic indexes for areas (cat 2039.0). Indexes range from 800 to 1200 and an index of 1000 represents the median. The higher the index the larger the proportion of advantaged residents in the postcode area of the respondent. 10.6 per cent of respondents could not be matched to a Socio-economic index in most cases because their postcode was not classified in 1996.

by recent labour market pressures, the magnitudes of the effects, as shown in Table 4 and 6 are small. ${ }^{25}$ A literal interpretation of these figures means that either the labour allocation decision is so sensitive over a 6 month period to wage variations that wages need not vary

\footnotetext{
${ }^{25}$ While competitive neo-classical theory predicts that wage levels will be determined by labour supply characteristics and the non-pecuniary aspects of given employments, wage changes should be observed as part of the short term equilibrating process. Unless, labour's mobility between jobs is either extremely sensitive or not at all sensitive to wage variations, then a change in wage will be expected to succeed a change in labour market balance.
} 
much to perform their allocative role or wages are not particularly sensitive to change in external labour market conditions in the short run.

Collectively the variables which are possible proxies for the bargaining power of workers have produced larger coefficients than the labour market variables. However, whether these are larger than they would have been during the pre-decentralisation period remain unclear due to lack of comparative data.

\section{Conclusion}

Labour supply characteristics such as educational attainment and age have some of the strongest effects on the probability that a person will get a pay rise and the size of the annual rise. Other measures of outside income - unemployment benefits and rent allowance - were not significant. Collectedly the bargaining variables, sex, part-time and full-time status and the level of aggregate wage disputation also appear to have an important role. Workers on individual contracts are most likely to achieve the highest wage outcomes, which is consistent with the prior view that the most highly and often specifically skilled workers are often employed on individual contracts. Workers on enterprise bargains, who are expected to be well organised, are most likely to achieve moderate wage rises and workers remaining on their old awards, the weakly organised, are most likely to gain either no pay rise or a pay cut.

This analysis cannot test for the effects of decentralisation of wage negotiations because it is not possible to estimate the size of wage rise these workers would have achieved under alternative wage systems. 


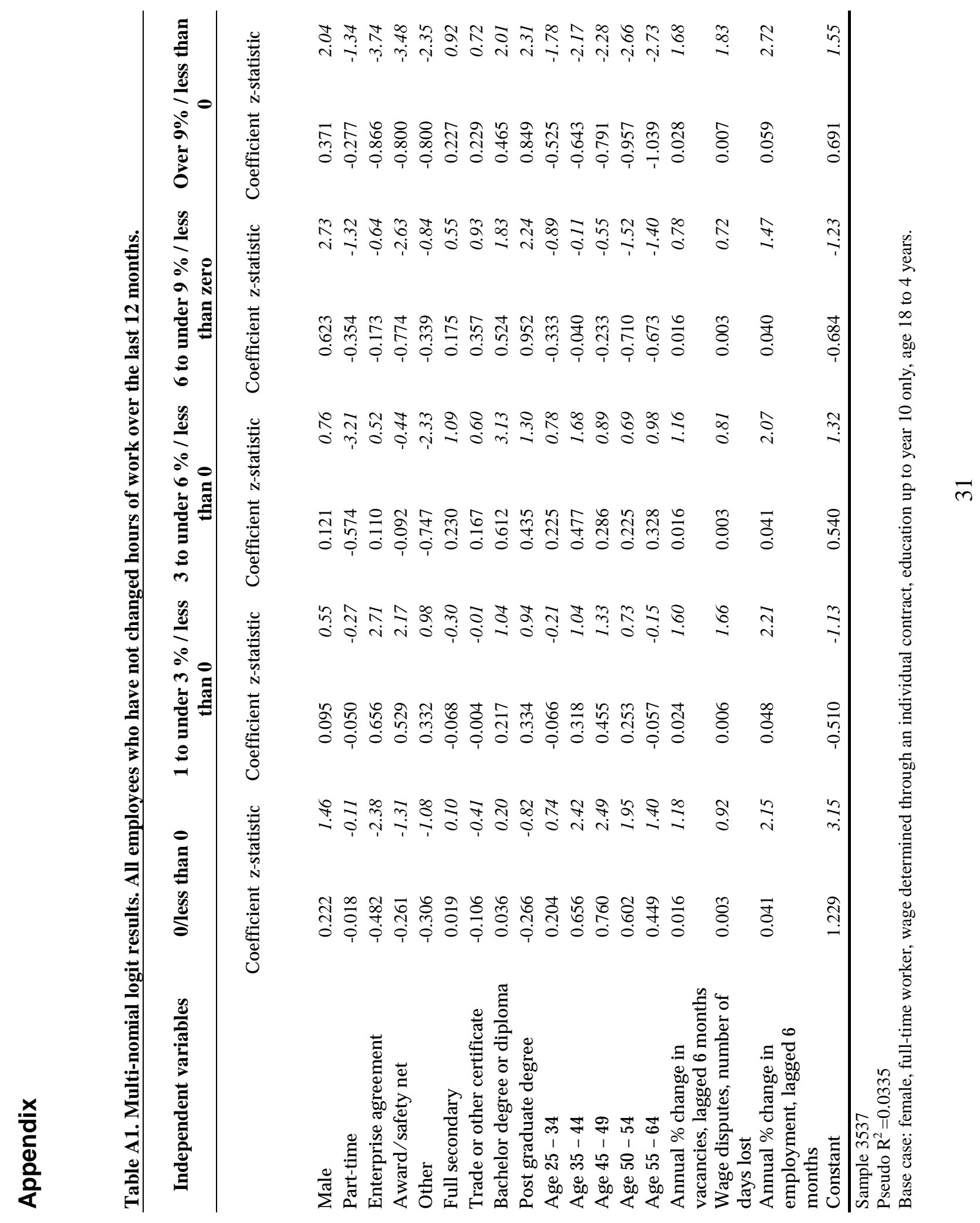




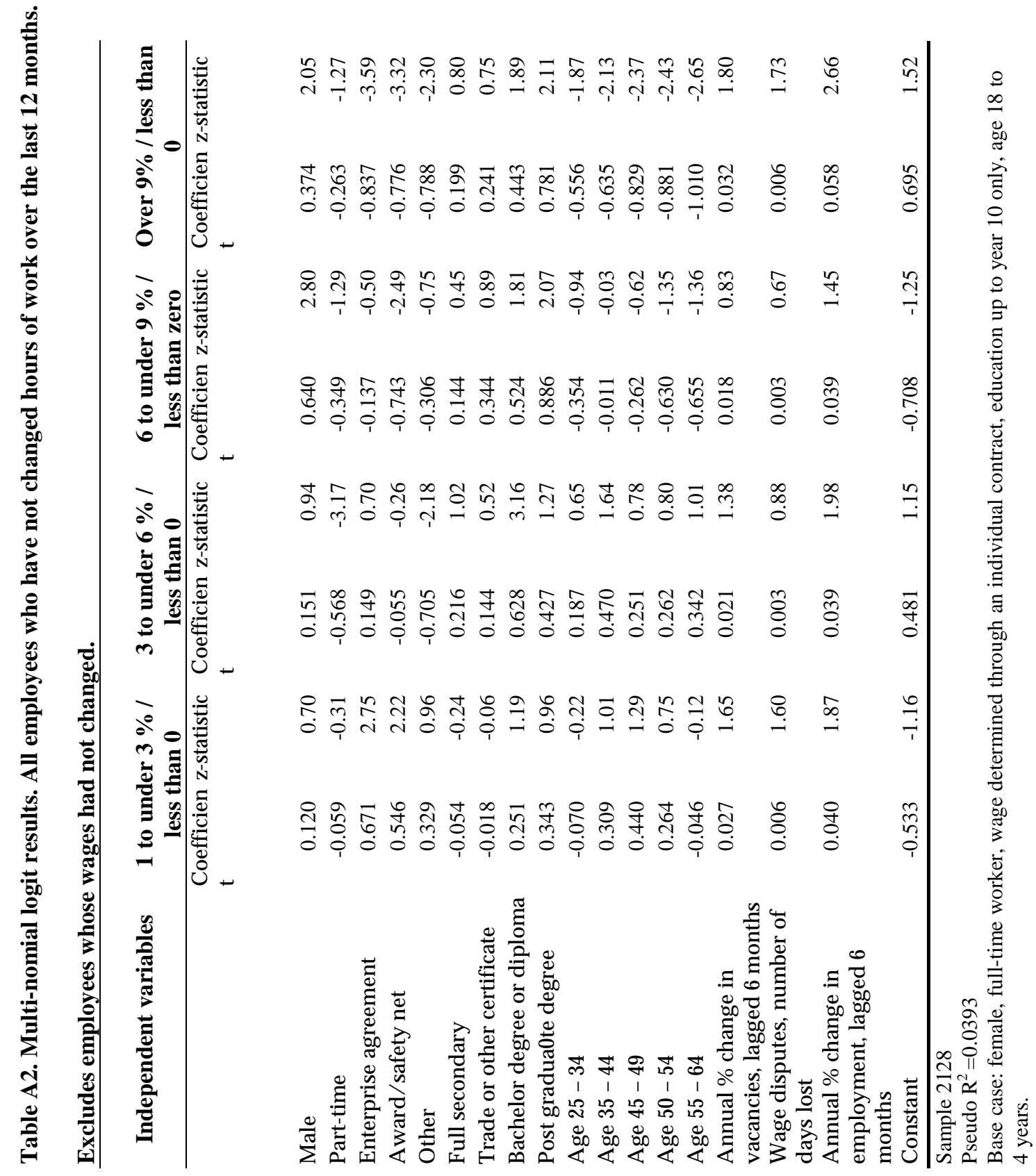

n 


\section{References}

Best, M. H. (1990) The New Competition, Polity Press., Cambridge.

Bewley, T. F. (1998), 'Why not cut pay?', European Economics Review, 42, 459-490.

Blanchflower, D. G. and Oswald, A. J. (1994), 'Estimating a wage curve for Britain 1973-90', Economic Journal, 104, 1025-1043.

Blanchflower, D. G., et al. (1990), 'Insider power in wages determination', Economica, 57, 143-70.

Borland, J. (1996), 'Earnings Inequality in Australia: Changes, Causes and Consequences', Economic Record, 75, 177-202.

Borland, J. and Suen, A. (1990), 'The Determinants of Individual Wages in Australia: Competitive and Non-Competitive Influences', Australian Economic Review, 4'90, $33-44$.

Borland, J. and Wilkins, R. (1996), 'Earnings inequality in Australia', Economic Record, 72.

Campbell, I. and Brosnan, P. (1999), 'Labour Market Deregulation in Australia: The Slow Combustion Approach to Workplace Change', International Review of Applied Economics, 13, 353-94.

Cartter, A. M. (1959) Theory of wages and employment, Greenwood Press., Westport, Conn.

Creedy, J. and McDonald, I. (1991), 'Models and trade union behaviour: A synthesis', Economic Record, 67, 346-359. 
Dabscheck, B. (1997), "Stolen Entitlements': The 1997 Living Wage Case', Economic and Labour Relations Review, 8, 129-42.

Dowrick, S. (1993), 'Enterprise Bargaining, Union Structure and Wages', Economic Record, 69, 393-404.

Fels, A. and Tran, V. H. (1981), 'Causal Relationships in Australian Wage Inflation and Minimum Award Rates', Economic Record, 57, 23-34.

Fernie, S. and Metcalf, D. (1995), 'Participation, Contingent Pay, Representation and Workplace Performance: Evidence from Great Britain', British Journal of Industrial Relations, 33, 379-415.

Gregory, R. G. (1993), 'Aspects of Australian and U.S. living Standards: The disappointing decades 1970-1990', Economic Record, 69, 61-76.

Gregory, R. G. and Vella, F. (1995), 'Real Wages, Employment, and Wage Dispersion in U.S. and Australian Labor Markets', Freeman, Richard B., , 205-26.

Hamberger, J. (1995), 'Individual Contracts: What Do They Mean for Australia?', Economic and Labour Relations Review, 6, 288-99.

Hancock, K. and Moore, K. (1972), 'The Occupational Wage Structure in Australia since 1914', British Journal of Industrial Relations, 10, 107-128.

Hieser, R. O. (1970), 'Wage Determination with Bilateral Monopoly in the Labour Market: A Theoretical Treatment', Economic Record, 46, 55-72.

Keating, M. (1983), 'Relative Wages and the Changing Industrial Distribution of Employment in Australia', Economic Record, 59, 384-97. 
King, J. E. (1997), 'Critical Notes on Labour Market Deregulation', Discussion Paper, 97.07, Schools of Economics and Commerce, La Trobe University, Melbourne.

King, J. E., et al. (1992), 'The Law of the Shrinking Middle: Inequality of Earnings in Australia 1975-1989', Scottish Journal of Political Economy, 39, 391-412.

Kirby, M. G. (1981), 'an Investigation of the Specification and Stability of the Australian Aggregate Wage Equation', Economic Record, 57, 35-46.

Loasby, B. J. (1983), 'Knowledge, learning and enterprise', In Beyond Positive Economics(Ed, Wiseman, J.), Macmillan,, London and Basingstoke, pp. 104-21.

Marshall, A. (1890) Principles of Economics, London, 8th edition.

Miller, P. and Mulvey, C. (1996), 'Unions, Firm Size and Wages', Economic Record, 72, $138-153$.

Mumford, K. and Dowrick, S. (1994), 'Wage bargaining with endogenous profits overtime working and heterogeneous labor', Review of Economics and Statistics, 76.

Nickell, S. and Kong, P. (1992), 'An investigation into the power of insiders in wage determination', European Economic Review, 36, 1573-1599.

Nickell, S., et al. (1994), 'Wages and product market power', Economica, 61.

Porter, M. E. (1990) The Competitive Advantage of Nations, Macmillan., London and Basingstoke.

Spenner, K. I. (1995), 'Technical change, skill requirements and education: The case for uncertainty', In The new modern time. Factors reshaping the world of work $(\mathrm{Ed}$, D.B., B.), State University of New York Press, Albany. 
Stegman, T. (1997), 'Implications for Wages Policy in Australia of the Living Wage Case', Economic and Labour Relations Review, 8, 143-55.

Stegman, T. (1999), 'On the Role of Regulation in Union-Employer Bargaining', Economic and Labour Relations Review, 10, 92-106.

Trivedi, P. K. and Rayner, J. (1978), 'Wage Inertia and Comparison Effects in Australian Award Wage Determination, 1964-74', Economic Record, 54, 195-218.

Tseng, Y.-P. and Wooden, M. (2000), 'Enterprise Bargaining and Labour Productivity: Evidence from the Business Longitudinal Survey', Melbourne Institute Working Paper, xx/00, MIAESR, University of Melbourne, Melbourne.

Webster, E. M. (1998) Labour as an asset: is it polarising the labour market?, In Melbourne Institute Working Paper No. 4/98, Melbourne Institute of Applied Economic and Social Research.

Webster, E. M. and Summers, P. (2000), 'The effects of labour market programs on wage inflation', Journal of Industrial Relations, 42, 383-397.

Withers, G., et al. (1986), 'Wage Adjustments and Labour Market Systems: A Cross-Country analysis', Economic Record, 62, 415-426.

Young, A. (1928), 'Increasing returns and economic progress', Economic Journal, 38, December. 